\title{
'Pirate will never stop; it's cyclical. If you push people hard enough, they'll find a mode of expression: A study of community \& pirate radio in Scotland
}

\author{
Christina Klos \\ Department of Communication Development and Social Change, Klein College of Media and \\ Communication, Temple University, Pennsylvania, USA
}

\begin{abstract}
.
The historical and present context of community and pirate radio in Scotland makes the case that community and pirate radio act as citizens' media, allowing Scottish voices a chance to actively participate in Scottish counter-narrative media representation. The history examined in this research includes: the union of Great Britain and colonization of Scotland, as means to argue that Scottish cultural identity and narrative has been historically silenced; the history of the United Kingdom's broadcasting legislation; and archival research into the history of the 1960's pirate Radio Scotland. I use two qualitative research strategies: (1) an ethnographic interview with a contemporary radio pirate Donald Stewart from Glasgow, Scotland and (2) a case study of Black Diamond Radio, a Scottish community radio station based in Midlothian. Data has been collected from interviews, archives, newspapers, government documents, relevant web-pages, and published reports. This research argues that when left out of the United Kingdom's media broadcasting, Scottish identity becomes lost and replaced with that of a homogenized, commodified West or a fictitious version of their own; local radio gives Scottish citizens media control through Scotland's newly legitimized community radio sector and the ever present illegal broadcasting of pirate radio. Both the Midlothian community and Glasgow youths restructured their identities together, not only by creating and sharing cultural artifacts within their communities, but also by creating a public space where community members can actively take part and participate in operations, conversations, and shared experiences- a fully Scottish narrative.
\end{abstract}

Keywords: Pirate Radio, Community Radio, Scottish Identity, Citizens’ Media 


\section{2nd world conference on research in SOCIAL SCIENCES}

19-21 March, 2021

Budapest, Hungary

\section{Introduction}

There's something about the process of getting together the tools, hardware, space, and community members to broadcast on the airwaves. Live radio broadcasting is no longer a majority favored media in much of the Western world- yet talking to the people who continue to participate in radio, often volunteering their own time and resources to the craft- I have discovered that radio broadcasting is not just about the product when created outside of commercial and institutional enterprises. Rather, the process is empowering, and set in the context of community support, shared knowledge, and participation in positive experiences with other community members. Described here is a type of media known as "citizens' media." Coined by Dr. Rodríguez (2011), citizens' media gives citizens the power to "name the world in their own terms," meaning people are able to use their own language, perception, and narrative to share their reality with others. In dominant media, the dominant narrative is not told from a local point of view, but from a dominant viewpoint held by those in power, recycled over and over regardless of viewership identity. If citizens "name the world in their own terms" then they can cover topics of local importance from their own, localized perspectives. By giving citizens the power to "name the world in their own terms" "Citizens' media trigger processes that allow individuals and communities ... [to] restructure their identities into empowered subjectivities strongly connected to local cultures ... Citizens' media are the media citizens use to activate communication processes that shape their local communities" (Rodríguez, 2011).

\section{Body of paper}

In Scotland, community radio licensing and pirate radio culture provide a space for Scottish citizens to participate in media broadcasting within the United Kingdom of Great Britain (UK), which is otherwise rare $^{1}$, as much broadcasted content (especially television) comes directly from England, specifically London. Imported media into Scotland is void of Scottish cultural content, leading to the further erasure of Scottish culture within the UK (Blain \& Burnett, 2008). This paper will not suggest what Scottish content should be when broadcasted, but rather argue for the importance of Scottish representation and participation, by showcasing how community-licensed and pirate radio in Scotland creates a public space for local Scottish voices within the UK to broadcast citizens' media.

Scotland is one of four home nations that make up the unitary sovereign country of the UK. For the purposes of this essay, it is necessary to understand that England and Scotland formed a union in 1706 that joined both countries into a unitary state known as Great Britain, due to Scotland's economic needs, as the country was going bankrupt and facing high levels of poverty, and England's desire to have political reign

\footnotetext{
${ }^{1}$ The internet is another space where Scottish media made by Scottish citizens can be found- but this media is often narrow-casted with limited and very specific target audiences- "digital space does not necessarily work to favor the needs of cultural geographies associated with small nations" (Blain \& Burnett, 2008, p. 16).
} 


\section{2nd world conference on research in SOCIAL SCIENCES}

19-21 March, 2021

Budapest, Hungary

over Scotland in order to keep their military interests and international relations aligned ("The Union of England and Scotland"). The union still kept the separate nations intact, but would ultimately lead to issues still faced today such as political representation, economic-inequity between nations, assimilation and/or acculturation of Scottish culture, and questions of identity- is one British, English, or Scottish and what does it mean to claim one over the other? (Webster, 1997). Additionally, Scotland can be viewed as a postcolonial state today- colonized by the UK. In the late 1700's through the 1800's, political powers within England pushed for Gaelic-speaking, Scottish indigenous populations, located in the Highlands, to relocate for more "economic landuse" of intensified sheep farming, which displaced entire communities. Further, the Gaelic community was exploited by "an active interference with language use through the eradication of Gaelic from the sphere of education as manifested in a series of Education Acts from 1872 onwards. Such education policy ensured the integration of the Gaelic speech community into English-language Britain" (Krause, 2005). Imposing language and religion are two of the main elements employed by colonial powers. Due to the complicated relationship between Scotland and the central government of the UK, Scotland has had a push for independence that grew especially strong in the 1990's, which lead to a vote on Scottish independence from the UK in 2014. In a close vote, Scotland voted to remain part of the UK (Erlanger \& Cowell, 2014). While this essay will be focused on community and pirate radio in Scotland, the historical and geographical context of Scottish radio is entwined with UK's radio broadcast history and current legislation.

In order to fully understand the mediascape of radio in Scotland today, one must review the history of radio in the UK, which began on October $18^{\text {th }}, 1920$, when the British Broadcasting Corporation (BBC) was founded by a group of radio manufactures and shareholders. BBC began broadcasting by 1922 . On January $18^{\text {th }} 1923$, BBC received official license from the UK government (Boel, 2011). "The government of the day worried that broadcasting was too important to be left to the market and set up an enquiry"- and so BBC became a public corporation under a Royal Charter, which provided the government a level of control (Cridland, 2015). "By the mid 1920s most of the UK population could listen to BBC radio programmes" which were aired on AM frequency (Office of Communications, 2020). BBC started by producing localized content, and by the 1930s, moved to broadcast both local and national content (Cridland, 2015). In 1939 due to the start of World War 2 (WW2), "BBC replaced regional medium wave broadcasts with a new nationwide channel, the Home Service...so enemy aircraft could not use local transmissions to navigate their way around UK air space" (Office of Communications, 2020). The Home Service continued broadcasting until 1967 (Office of Communications, 2020). The switch to a single, nationwide radio channel limited local programming and participation in radio during and after WW2. After the war, in the 1950's, BBC once again "was given the means to expand its activities and operate local or regional radio stations" (Cammaerts, 2009). In the 1960's BBC's monopoly of the airwaves was challenged by illegally broadcasted "pirate" radio stations, "operating from fixed structures or broadcasting from ships in 


\section{2nd world conference on research in SOCIAL SCIENCES}

19-21 March, 2021

Budapest, Hungary

international waters beyond the reach of domestic legislation" (Cammaerts, 2009). ${ }^{2}$ One of these infamous pirate stations was the offshore Radio Scotland, broadcasting into Scotland and Northern Ireland, whose detailed history will be reviewed in the next paragraph. Pirate stations airing into the UK were quite successful, backed by local advertising, these stations often playing the youth- orientated pop and rock music that $\mathrm{BBC}$ aired limitedly, due to agreements with the Musicians Union that restricted "needle time"- the amount of time a broadcasting station can air recorded music (Witts, 2012). Pirate radio stations were forced off the air in 1967 due to the Marine Broadcasting Offences Act, the UK government's solution to unlicensed broadcasting (Cammaerts, 2009). "The Act barred British citizens from participating in so-called "pirate radio" stations that broadcast from outside UK territory" (Jurist, 2009). In 1973, commercial radio is launched in the UK, licensed through the Independent Broadcasting Authority (IBA), in hopes of capturing the audiences who were drawn to the illegal pirate stations of the 1960s. These commercial stations "were local (owned and run), generally covering cities or counties...localness has, therefore, been an important feature of commercial radio since its inception" (Cridland, 2015). The licenses provided by the IBA "theoretically allowed community stations to exist,... [but] provided a very strict regulatory framework that was only beneficial for commercially-driven local radio" (Cammaerts, 2009). Due to the restrictions set by the IBA, citizens who wanted a local, non-commercialized media space could not do so legally. UK community based radio initiatives were thus operated illegally, though they lobbied for official recognition through the Community Radio Association (CRA). While these illegally run community radio stations met community needs, in order to continue operations many began to seek local funding through advertisements. "Despite the lobby efforts of the CRA for political recognition, the illegal pirate stations were targeted repeatedly by the Department of Trade and Industry (DTI), whose actions were aimed at shutting down the broadcasting operations of illegal broadcasters" (Cammaerts, 2009). Not until 2002 did the UK consider a third sector of radio outside of public broadcasting and commercial, which lead to the 2003 Communication Act. The 2003 Communication Act made space on the airwaves for a small number of access radio stations to broadcast, which "were intended to develop the concept and model of community radio in the UK" (The Scottish Government, 2012). In 2005, community radio is legitimized and granted full licenses through "a newly formed media regulator, Ofcom" (Cammaerts, 2009). As of 2011, 231 community radio stations have been licensed in the UK, with 18 of those in Scotland (The Scottish Government, 2012). One of the primary characteristics of these community radios, which must be proven through the application process, is "the delivery of social gain," especially for local and underserved populations, ensuring access and participation opportunities (The Scottish Government, 2012). Even with the creation of a community radio sector, illegally broadcasted "pirate radio" still exists in the UK due to the limitations created by regulations, cost, and limited license availability (The Scottish Government, 2012). Those involved in pirate radio face penalties if caught. The penalty for illegally broadcasting (also called pirate radio in Ofcom's documentation) in the UK is a fine set

\footnotetext{
2 The phrase "pirate radio" used to name illegally broadcasted radio programming, comes from the imagery of these off-shore ships that aired some of the first illegally broadcasted radio content.
} 


\section{2nd world conference on research in SOCIAL SCIENCES}

19-21 March, 2021

Budapest, Hungary

at an unlimited amount, and a prison sentence of up to 2 years, as illegal broadcasting is considered a criminal offense. Ofcom suggests that there is a link between illegal broadcasting and serious crimes related to drugs and weapons. A person convicted of illegally broadcasting is prohibited from obtaining a radio license for 5 years. Ofcom has a variety of pirate radio report forms and hotlines for citizens to call to report illegal broadcasting in their area (Office of Communications, 2019). While the UK's radio history is set in public broadcasting, the influence of pirate radio would impact legislation allowing for commercial and community radio licensing.

The history of Radio Scotland is one of pirate radio success and loss; a history that is still discussed and honored today as a part of Scottish broadcasting pride. In order to navigate around the UK's strict broadcast laws, Radio Scotland (and other pirate stations) broadcasted from just outside of UK territory, in international waters. On December $31^{\text {st }}, 1965$, Radio Scotland aired for the first time, transmitting "from the Comet, a sixty year old engine-less [towed if moving long distances] former Irish lightship" (Offshore Radio). These were their first aired words, as said by Tommy Shields just before midnight:

Good evening, this is a proud moment for me, and indeed for all of us here, for after many months of trial and tribulation Radio Scotland is now a floating reality. Thanks to the skill and ingenuity of a dedicated band of radio engineers and the loyalty of our team, we have been able to convert a former Clyde-built light ship, the Comet, into one of most modern offshore broadcasting stations in the world (Shields, 1965, audio).

Radio Scotland would go on to "broadcast popular music and Scottish voices to millions, filling the void created by the monopoly of BBC radio" (Wilson, 2020). Radio Scotland was the first broadcast station to cater directly toward Scottish listeners, playing the music they wanted to hear and featuring Scottish voices. Radio Scotland last aired on August 14 ${ }^{\text {th }}, 1967$ due to the Marine Broadcasting Offenses Act, which effectively shut down radio pirates who were airing from the sea. Radio Scotland aired for 22 months, and in that time "Radio Scotland played thousands of records, employed about 20 disc jockeys, and won more than two million regular listeners" (Buckhaven.info). Though Radio Scotland's broadcast ended, it left an impact on Scottish radio, by influencing BBC to create their own "Radio Scotland" station (yes, they repurposed the pirate station's name). BBC's Radio Scotland produced content for the Scottish population specifically, instead of broadcasting programming into Scotland that was made for an English audience (Wilson, 2020).

\section{Community \& Pirate Radio in Scotland: A Citizens' Media Case:}

One key part of Scottish citizens' media today takes the form of licensed community radio; what follows is an over-view of community radio in Scotland, as well as a close study of a long-standing community station to provide practical context. "Community radio operates as a third tier alongside the BBC and commercial radio channels" (The Scottish Government, 2012). As stated previously, Scotland has 18 licensed community stations which broadcast a variety of content including: religious, health promotion, black and minority ethnic, geographically localized, Scottish music, 


\section{2nd world conference on research in SOCIAL SCIENCES}

19-21 March, 2021

Budapest, Hungary

military, and disability (The Scottish Government, 2012). In order to become a licensed community station, one's application must explain specific plans to meet and deliver on their key commitments to the community. These key commitments must be based on the following principles set by the UK as:

be for the good of the public, deliver social gain, be non-profit making, provide managerial and operational opportunities for target community members, be accountable to the community concerned, serve underserved groups, facilitate discussion and the expression of opinion, strengthen links within and facilitate better understanding of a particular community (The Scottish Government, 2012, p.9).

One of the biggest struggles community radio in Scotland faces is a lack of guaranteed financing (The Scottish Government, 2012). Funding for community radio comes from donations, public funding (for example government grants), and advertising (so long as all profit goes directly back into the station's operating costs). Many of these forms of financing are subject to fluctuation depending on listenership, volunteers, and available public funding. Community radio cannot gain over 50\% of their profits from advertising- and any profit produced must "improve the service or delivery of social gain" (The Scottish Government, 2012). A key characteristic of community radio in Scotland is volunteerism, where volunteers "take on a variety of roles from presenting to marketing, and journalism... a number of stations are entirely volunteer run" (The Scottish Government, 2012). In terms of demand for community radio, the Scottish Government published research in 2009 that polled general attitudes on broadcasting, including community radio. The results showed that listener rates for community radio were low- 2 percent of respondents claimed they had listened in the last 7 days. Although, particular areas within Scotland, the Highlands and the Islands, showed 10 percent of respondents listening to community radio (The Scottish Government, 2009). While listenership was low, community radio was valued by a much larger percentage. 49 percent of the respondents specified that having a local community radio station was important to them (The Scottish Government, 2009). Overall, what grounds community radio as a form of citizens' media is not based in large listenership; what grounds community radio as a form of citizens' media are the guiding principles at the core of community radio foundation, and the emphasis and use of community member volunteers to run and produce content for stations.

One example of a community radio station that acts as citizens' media is Black Diamond 107.8 FM, broadcasting to Midlothian in the east-central low-lands, bordering Edinburgh. Black Diamond community radio provides a space for the citizens of Midlothian to "name the world in their own terms," as it is completely volunteer run by citizens of Midlothian, provides training to volunteers so that community radio is accessible to anyone interested, and uses their platform to amplify voices within their community that do not often have a platform- youth and the elderly (Black Diamond, About Us). The station runs on-air 24/7, and includes "a range of programmes from our regular community focused daytime output... [by an all-volunteer staff] who go out of their way to create programmes and content for Midlothian... and some of the best specialist music programmes (in our opinion) you will find on Scottish radio" (Black 


\section{2nd world conference on research in SOCIAL SCIENCES}

19-21 March, 2021

Budapest, Hungary

Diamond, About Us). The station's mission (which is quite long) includes seven segments focused on:

- socially inclusive education and training for all community members for personal growth and skill-building,

- encouragement for youth, elder, and unemployed participation,

- promote social inclusion between diverse members of the Midlothian community,

- facilitate peer education projects in the nonprofit sector with local community,

- put surplus towards growth of charitable aims,

- work to facilitate partnerships with local institutions, charities, and all "community benefiting bodies" in order to further support the community (Black Diamond, About Us).

The above mission of Black Diamond Community Radio is centered around providing the space, education, and tools for community members to work together and create anything they would like for their community, so long as the product promotes inclusivity. Community members are then able to participate in a variety of ways, through the vehicle of community radio, in shaping, discussing, and sharing their experiences of the Midlothian Community together. Online, the station is inviting of newcomers and future volunteers. Under a clearly labeled tab titled "Volunteer With Us" the following is written: "Black Diamond FM are always looking for people to get involved in the station. If you want to dedicate any time to helping bring community radio in Midlothian forward then why not contact us now! There are many voluntary positions available. Call the office now or e-mail," and provides contact information (Black Diamond, Volunteer With Us). Another tab, titled "Train With Us" shares a similar message: "Black Diamond FM provides various training opportunities for individuals and organizations who live in, and around Midlothian. If you have ever been interested in the media industry or simply want to build your confidence then why not get in touch and join our team of volunteers!" also providing contact information (Black Diamond, Train With Us). By making the inquiry process as simple as reaching out, community members have the efficacy to easily become part of the station, which shows that the station is dedicated to their mission of inclusivity. While the station has a large variety of "presenters" who are radio hosts, the programming remains structured and organized every day. For example, the station has set programming each day such as the "Breakfast" program that runs every weekday morning. The hosts of "Breakfast" change daily and sometimes hourly, as a number of volunteers pick weekly time slots to host the show, and are able to play their own music and host their own content, which includes: "International and Local News, Road Traffic reports for the area, Weather, as well as informed opinions and interviews" (Black Diamond, Breakfast). Locals are also encouraged to call into Black Diamond any time in the morning, to share "requests, give us up to date information on the roads, or other events [in the community]" (Black Diamond, Breakfast). Through their well-organized programming, the station is able to engage listeners with structured content, while also providing a platform for all their volunteers (who have completed the proper training) to "name the world in their own terms" through their choice of content and presentation of self on-air. 


\section{2nd world conference on research in SOCIAL SCIENCES}

19-21 March, 2021

Budapest, Hungary

Another key part of Scottish citizens' media today takes the form of pirate radio; what follows is a description portrait of pirate radio in Scotland, from the perspective of radio pirate Donald "Dee" Stewart of Glasgow. Britannica defines pirate radio as "unlicensed radio broadcast intended for general public reception" (Ray \& Pidgeon, 2012). The phrase "pirate radio" comes from the infamous off-shore illegal broadcasters discussed earlier in this essay. "While many pirate radio stations have been short-lived low-power entities operated by amateur hobbyists, others have been elaborate professional undertakings that skirted government regulation" either by remaining outside of national boundaries (Ray \& Pidgeon, 2012), or by remaining in constant movement transmitting from a variety of locations, without providing personal identifiers on air (D. Stewart, personal communication, 2020). In the UK, Scotland included, "large-scale pirate operations were in decline" from the 1970's and onward due to the legislation banning off-shore broadcasters, and for on-shore operations, the market was becoming saturated with popular commercial radio stations and the rising fame of BBC's Radio 1 (Ray \& Pidgeon, 2012). Stewart and other, more alternative news sources tell the story of pirate radio after the fall out of large-scale operations in the 1970's. Here, a rising sub-culture in the late 1980's through early 2000's supported small-scale pirate radio, built around a culture of "house music"- extremely fast electronic music made popular by DJ's who mixed music that made people want to dance. Often, a particular "song" wasn't popular within the house music scene, rather it was a particular DJ whose "relationship with the music business allows an audience to hear music that would otherwise probably not be published by record companies. The most celebrated DJs are often involved in re-mixing other artists' recordings, providing a variety of interpretations of pre-existing material" (Langlois, 1992). During this time in the UK, large numbers of people would get together in dance halls and clubs to listen to DJs, and these gatherings would become known as raves. "Raves are characterized by their long duration, high-volume music and a particular dream-like ambience created by special effects, lighting and music" (Langlois, 1992). Due to the drug usage that cohabited house music and rave culture, authorities often shut down raves (Langlois, 1992), and pirate radios would pick up where the music left off (D. Stewart, personal communication, 2020). Often, radio pirate DJ's would play their own sets to gain a following that would hopefully lead to fame. One such pirate was Douglas "Dee" Stewart. Dee became interested in pirate radio at the age 11, when he accidentally stumbled upon a radio pirate station playing an explicit song:

"I was 11 when I first heard a pirate station. I remember tuning the FM band when I was in bed at night, when I came across a song that had swearing in it. The song was Hey Santa Claus by Kevin Bloody Wilson. I remember turning it down low, as I didn't want my mum to hear or she would have turned it off. The next day I tried to listen to the same pirate radio station, but it was off air. I started asking friends and family about the station, and I learned then it was pirate. A year later I got into $\mathrm{CB}$ radio, my friend got a hand held $\mathrm{CB}$ for a birthday and I loved it and was smitten by it" (D. Stewart, personal communication, 2020). 


\section{2nd world conference on research in SOCIAL SCIENCES}

19-21 March, 2021

Budapest, Hungary

At the age of 14 in the early 2000's, Dee wanted to become a DJ in the rave scene, and would practice in his room. One day he realized that he had the skills to get himself on air, and decided to try and DJ as a radio pirate.

"So, I decided to start a station. Back then internet was different if you had itit made it very difficult to source where to buy broadcast equipment. It was all cloak and dagger, hush hush. I got detail of a company that would supply a build yourself kit for under $£ 100$, so I got and built the kit with the experience of electronics I had gained while using CB radio, the kits were very simple to build" (D. Stewart, personal communication, 2020).

The first legitimate pirate station that Dee ran was called anonymousFM, and transmitted on 102.1FM in Glasgow. He and some friends ran it together, all between the ages of 14-17. Dee's anonymousFM would draw enough local fame and recognition that he would fulfill his DJ dreams on a small scale, DJing at local clubs throughout Glasgow. Here he describes the technical side of the experience:

"The first station I set up was in some high rise buildings, as the higher you can get the antenna the more area can get a signal. So with that we were using a bedroom with a decorators pasting table with all the equipment, total cost of around $£ 500$ for turntables, mixer, amps, mics, speakers, vinyl, and the transmitter. A week or so before turning on for first time we printed off around 100 A4 sized papers with a question mark and 102.1FM printed on it. We put these where they could be seen by a high volume of people. At this point we decided on "anonymousFM" as no one knew who we were- well not at the start of it all anyway. The popularity of the station grew almost instantly. Within the first month we had to have additional mobile phones as we could not compete with the call demand. We also started to bring other DJs on board" (D. Stewart, personal communication, 2020).

Dee recalls that as anonymousFM was on air, other local pirate stations were getting caught and shut down. Soon the local pirate stations in Glasgow would contact each other immediately after one got caught on air, or if they saw police or Department of Trade and Industry (DTI) authorities driving around. After 6 months of stationary broadcasting, Dee realized anonymousFM would need to be come transitory in order to remain on air longer, though eventually they got caught.

"It became a game of cat and mouse. We were moving locations each broadcast, sometimes during a live broadcast with a backup clone system in another location. We would see them driving around in their big black government cars trying to track our station and for a while it worked. One time we did not change location the whole weekend and of course got a knock at the door while live on air. It was two members of the radio society of Great Britain, two members of the DTI, together with 8 police. Some would say they came heavy handed, but we had built up this whole image, saying we had armed security outside and warned we were ready for the coppers as we would go to war before we let them shut us down" (D. Stewart, personal communication, 2020).

Dee and his friends would go to court, lose their equipment, and be banned from obtaining a radio license for 5 years. Dee went on to run two additional pirate stations that got shut down. Today, he is banned completely from obtaining a radio license- but 


\section{2nd world conference on research in SOCIAL SCIENCES}

19-21 March, 2021

Budapest, Hungary

has joined the Radio Society of Great Britain, and transmits pirate broadcasts on occasion for fun. He also builds equipment for other young pirates today, though he shares that pirate radio is dying off in the age of internet. When I asked Dee about the meaning behind his youthful, pirate radio, house music broadcasting, he shared:

"Doing live mixes on air was about sharing the same close friends and family you get from house partying. The more people that were involved, the more you had a feeling of being part of something bigger than one person, bigger than yourself, where everyone was on the same wave length. For once, life wasn't about making money or protesting the government or anything, it was about enjoying the moment that night, and hoping that other people did too" (D. Stewart, personal communication, 2020).

While Dee believes pirate radio is slowly being replaced with online platforms, others from the pirate scene in Scotland argue that pirate radio will always remain.

"Do a radio scan. You'll find them. You can still spot rigs and aerials. They're still there - even the ones that have been denying it for the past ten years. Pirate will never stop; it's cyclical. If you push people hard enough, they'll find a mode of expression. The internet has been pretty cool for that, but it's not the be-alland-end-all" (Hart, interview with Nicolov, 2017).

Pirate radio is citizens' media because it allows citizens to name the world in their own terms, where "in their own terms" is key. Most forms of broadcast ${ }^{3}$ to a general, local audience require institutional terms. Even applying for a community radio license comes with institutional terms. For pirate radio, citizens who have the knowledge to engage in pirate broadcasting truly do so at their own terms- they choose the location, the time, the content- regardless of regulations. When I think about Dee, I wonder "how else were a bunch of poor youths living in the housing projects of Glasgow going to get access to the public sphere without taking access into their own hands?" Scotland's youth culture of the late 1990's and early 2000's does not appear to be the most politically constructive identity transformation from an outsider's perspective, but I'd like to share another side. Pirate radio gave youth a voice and a place to showcase their creativity and build community with one another- especially when physical gatherings of music and expression were shutdown. Youths in Scotland illegally broadcasting house music were engaged in a political act against the commodification of goods, and were building bridges of acceptance and inclusivity of race, religion, and sexuality during a time where many individuals were divided and marginalized based on their identity. As Dee explained to me in our interview, a lot of people in Scotland rely on their identity to shape their world- it tells them who to interact with, what type of job to have, and dictates beliefs. For Dee, who tells me his identity is of a white, protestant, and Scottish male (while feverishly repeating that it doesn't mean he is either racist or cares about my religion, because he is in fact, not religious), radio helped him become part of a diverse community different from himself, largely because entry into the community begins anonymously, and house music makes everyone come together,

\footnotetext{
${ }^{3}$ I say "most forms" because the internet can be considered a form of broadcast, however it often has niche target audiences that do not reach a general, local community audience in the same way a radio or TV broadcast can.
} 


\section{2nd world conference on research in SOCIAL SCIENCES}

19-21 March, 2021

Budapest, Hungary

dance, and be happy. "You couldn't help but come together, it didn't matter who you were, there wasn't any conflict" (D. Stewart, personal communication, 2020).

\section{Conclusion}

In a small country like Scotland, where most of the media is imported from somewhere else, it's hard to find media artifacts that can be shared with others; if a local narrative, story, or other artifact is produced, it's hard to find a platform where one can share it with others. Thus, Scottish culture and identity become lost and replaced, often with that of a homogenized, commodified West or a fictitious version of their own, because Scottish citizens are unable to use media to communicate their own unique experiences, expressions, and perceptions with one another (Blain \& Burnett, 2008). "Scotland.. has struggled with its history and identity. Representation, whether on page, stage, or screen, has played a crucial role in that struggle" (Sillars and Macdonald, 2008). Local radio, however, gives Scottish citizens media control through Scotland's newly legitimized community radio sector and the ever present illegal broadcasting of pirate radio. Community and pirate radio provide a localized, noncommercial, public space where Scottish citizens can develop and produce citizens' media that "names the world in their own terms." For example, entirely volunteer run Black Diamond community radio gives local Midlothian citizens the tools, training, and platform to fully participate in radio broadcasting for their community. Additionally, pirate radio stations like Dee's anonymousFM gave Glasgow youth a platform to share their uncommodified, creative works, and promote a diverse and inclusive youth community. Both groups, the Midlothian community and the community of Glasgow youths were restructuring their identities together, not only by creating and sharing cultural artifacts within their communities, but also by creating a public space where community members can actively take part and participate in operations, conversations, and shared experiences.

\section{References}

Black Diamond Radio. About us. http://blackdiamondfm.com/about

Black Diamond Radio. Breakfast. http://blackdiamondfm.com/programmes/breakfast

Black Diamond Radio. Contact us. http://blackdiamondfm.com/contactus

Black Diamond Radio. Train with us. http://blackdiamondfm.com/contactus

Blain, N. \& Burnett, K. (2008). A cause still unwon: The struggle to represent Scotland. The Media in Scotland, 3-20.

Boel, H. (2011). European MW/LW history: United Kingdom. Radio Heritage. https://www.radioheritage.net/europe/countries-uk.htm

Buckhaven.info Radio Scotland. Buckhaven [website with information about town]. http://www.buckhaven.info/html/radio_scotland.html

Cammaerts, B. (2009) Community radio in the West: a legacy of struggle for survival in a state and capitalist controlled media environment. International Communication Gazette, 71(8), 635-654. 


\section{2nd world conference on research in SOCIAL SCIENCES}

19-21 March, 2021

Budapest, Hungary

Colonial Williamsburg Foundation. The Union of England and Scotland. Our American Revolution.

http://www.ouramericanrevolution.org/index.cfm/page/view/p0116

Cridland, J. (2015, October). The history and development of radio in the UK. Media Info.

Erlanger, S. \& Cowell, A. (2014, September). Scotland rejects independence from United Kingdom. The New York Times, A1.

Jurist. (2009). Marine Broadcasting Offences Act takes effect in UK. Jurist Legal News and Research Services Inc. https://www.jurist.org/thisday/2009/08/14/marinebroadcasting-offences-act-takes-effect-in-uk/

Krause, C. (2005). Gaelic Scotland - A postcolonial site? In search of a meaningful theoretical framework to assess the dynamics of contemporary Scottish Gaelic verse. ESharp, 6(1), 1-22.

Langlois, T. (1992). Can You Feel It? DJs and House Music Culture in the UK. Popular Music, 11(2), 229-238.

Nicolov, A. (2017). The history of UK pirate radio - and why it's still here. Dazed. https://www.dazeddigital.com/music/article/34394/1/pirate-radio-history-andfuture

Office of Communications. (2019). Illegal broadcasting (pirate radio). Ofcom. https://www.ofcom.org.uk/spectrum/interference-enforcement/spectrum

offences/ illegalbroadcast

Office of Communications. (2020). 100 years of radio since Marconi's big breakthrough. Ofcom. https://www.ofcom.org.uk/about-ofcom/latest/features-andnews/100- years-of-radio

Offshore Radio. The Radio Scotland Story. The Pirate Radio Hall of Fame. http://www. offshoreradio.co.uk/scot.htm

Shields, T. (Host). (1965, December 31). [First opening words of Radio Scotland]. Offshore Radio. http://www.offshoreradio.co.uk/audio/tvs1.mp3

Sillars, J. and Macdonald, M. (2008). Gender, spaces, changes: Emergent identities in Scottish transition. The Media in Scotland, 183-198.

Ray, M. \& Pidgeon, J. (2012). pirate radio. Britannica Academic. Encyclopedia Britannica.

https://academic-eb-

com.libproxy.temple.edu/levels/collegiate/article/ pirate-radio/477556

Rodríguez, C. (2011). Citizens' media. Encyclopedia of Social Movement Media, 98103.

http://search.ebscohost.com.libproxy.temple.edu/login.aspx?direct=true $\& d b=e$

$000 \quad \mathrm{xna} \& \mathrm{AN}=474298 \&$ site $=$ ehost-live \&scope $=$ site

Scottish Government. (2009). Public Attitudes Towards Broadcasting in Scotland 2009, Scottish Government,

https://www2.gov.scot/Resource/Doc/299585/ 0093399.pdf

Edinburgh.

Scottish Government. (2012). "We are community builders, part of the fabric": A review of community radio. National Local Service. https://www.nls.uk/scotgov/2012/ 9781780456799 .pdf

Webster, B. (1997). Medieval Scotland: The making of an identity. Palgrave, London. 


\section{2nd world conference on research in SOCIAL SCIENCES}

19-21 March, 2021

Budapest, Hungary

Wilson, S. (2020, October). The radio pirates who brought the swinging 60s to Scotland. The Scotsman. https://www.scotsman.com/heritage-andretro/retro/radio-pirates- who-brought-swinging-60s-scotland-3002684

Witts, R. (2012). Needle Time: the BBC, the Musicians' Union, popular music, and the reform of radio in the 1960s. Popular Music History, 7(3), 241-262. 